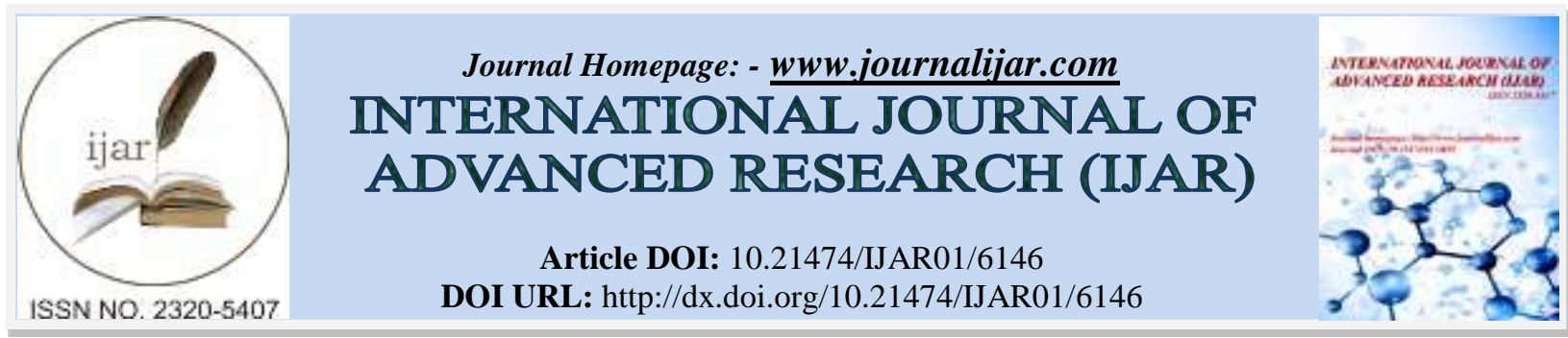

RESEARCH ARTICLE

\title{
EFFECTIVENESS AND IMPACT STUDY OF STUDENT IN ENTERPRISE PROGRAM (SIEP) WEE YU GHEE.
}

Mohamed Dahlan Bin Ibrahim.

Faculty of Entrepreneurship and Business, Universiti Malaysia Kelantan.

\section{Manuscript Info}

Manuscript History

Received: 23 October 2017

Final Accepted: 25 November 2017

Published: December 2017

\begin{abstract}
To increase entrepreneurial skills and promote entrepreneurial culture among students, Universiti Malaysia Kelantan embarks on its signature program called 'Student In Enterprise Program', commonly known as SIEP. This program requires students to complete a minimum of 10day attachment at any chosen small and medium enterprise, in their first, second and third year of studies. SIEP is a contemporary beyondclassroom initiative which aims at developing entrepreneurship competencies among students. It integrates different learning pedagogies attained through observations, inquiries, hands-on experience, real life case studies and simulation. This research is done to gauge students' perception on SIEP; examine program effectiveness as well as determine the impact brought about by SIEP. Data was collected from students across multiple disciplines from different faculties. Significantly, findings show majority of the respondents reported positively on the attributes, skills and functional knowledge attained after SIEP. Several feedback was gathered over the administration of pre-SIEP and post-SIEP and some practical recommendations were forwarded by the students.
\end{abstract}

Copy Right, IJAR, 2017,. All rights reserved.

\section{Introduction:-}

Student In Enterprise Program, also known as SIEP is one of the experiential learning activities initiated by Universiti Malaysia Kelantan (UMK). SIEP has been implemented since the establishment of UMK in year 2007. SIEP requires students of all faculties to gather work experience by seeking short term attachment with any small and medium enterprises (SMEs) located within their residential during their semester break. The attachment should last for a minimum of 10-14 days or even longer, depending on the mutual consent between the student and the manager or owner of SME.

Having completed a full cycle of SIEP whereby the first batch of UMK graduates was conferred in UMK Inaugural Convocation held in September 2011, this research aims to achieve the following objectives:

- To gather students' feedback pertaining to

(i) Registration, administration and procedures followed before SIEP attachment;

(ii) Experiences gained during SIEP attachment; and

(iii) Thoughts, feelings and lessons learnt after SIEP attachment.

- To determine the effectiveness and impact brought about by SIEP; and

- To forward constructive suggestions addressing rooms for improvement 


\section{Background:-}

SIEP is a contemporary beyond-classroom program which aims at developing entrepreneurship competencies among students. It integrates different learning pedagogies attained through observations, inquiries, hands-on experience, real life case studies and simulations. Students are required to register for SIEP during their Year 1, 2 and 3 semester breaks. Registration includes completing registration form distributed by the respective Faculty and getting the permission from SME of their choice. Each SIEP is unique and relevant because different assignments are imposed on the students as they progress through their years of study. Overall, the learning objectives could be summarised as follows:

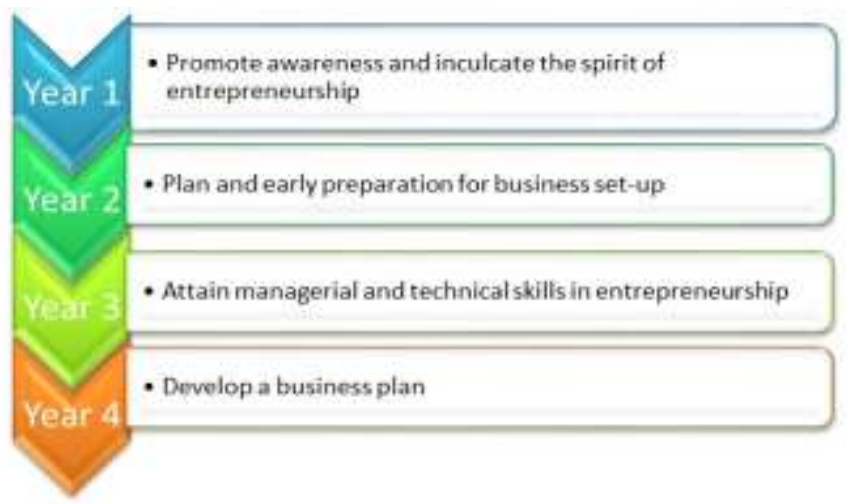

During Year 1 SIEP attachment, students should be aware of prerequisites knowledge about entrepreneurship and get acclimatized with enterprising and entrepreneurial culture. Year 2 SIEP exposes them to various opportunities and get prepared for the business world. Year 3 SIEP completes them further with sets of managerial and technical skills in entrepreneurship which lead them to possible business start-up upon graduate. The learning outcomes expected of students are:

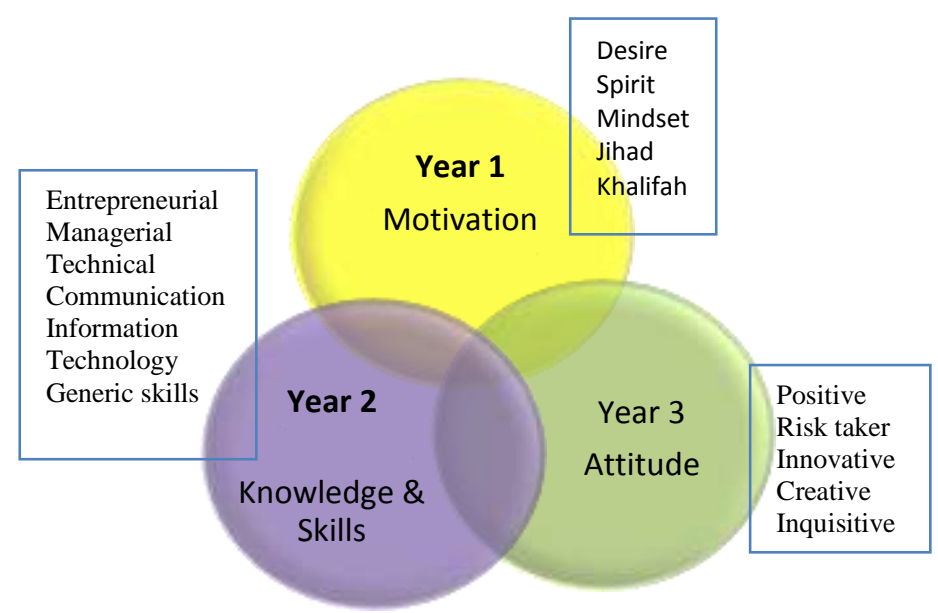

Students are provided a logbook to record all duties and responsibilities which take place during their SIEP attachment. Upon completing the cycle of each SIEP, students are required to produce a report and this will be assessed by their academic advisors.

Assessment criteria for SIEP includes the following:

- $\quad$ Report and feedback from the employer $(10 \%)$

- Individual written report $(50 \%)$

- Daily logs (10\%)

- Oral presentation $(30 \%)$

Individual report has to be written in English and should consist of the following contents: Introduction, SIEP Learning Objectives, Learning Outcomes, Discussion and Recommendations. Oral presentation is conducted when students return from their semester break, usually in the third week when all reports are submitted to the respective academic advisors. The presentation is assessed based on the following criteria:

- Contents $(10 \%)$ 
- Language proficiency (5\%)

- Expression of ideas/ Appearance/ Entrepreneurial Attributes (10\%)

- Question and answer (5\%)

Since employer is the best party in assessing student's performance at work, there are only two grades awarded for SIEP, namely PASS (50\% and above) or FAIL (49\% and below). Every student who completes SIEP on time and submit the required reports as well as present reasonable findings in class would easily attain a 'PASS' every semester. Though rare, students who attain 'FAIL' for any SIEP attachment would have to re-register and complete it in their next semester break.

\section{Research Methodology:-}

To address the research objectives stated earlier, the researchers decided to design survey instrument to gauge students' perceptions and examine their feedback on SIEP related learning experiences. A focus group discussion was held among twelve students representing all the faculties who have completed at least two cycles of SIEP and these selected students were of mixed genders, different year of studies, multi-disciplinary and multi-ethnic.

The outcome of discussion led to the formulation of survey instrument which can be seen in Appendix A. Section A of the questionnaire asks for the demographic details of the student; this is followed by Section B which examines the administrative and procedures before SIEP attachment; Section $\mathrm{C}$ gathers their learning and working experience during SIEP attachment and Section D gauges the learning outcomes and their overall perceptions and satisfaction towards SIEP program. Lastly, Section E compiles the attributes, skills and functional knowledge gained through SIEP. After conducting pilot test which involved twenty students, data collection was executed based on cluster sampling (by faculty and year of study).

\section{Summary of Findings:-}

To ensure there is an internal consistency among the items shown in the summated scale, the reliabilities for all the constructs are measured through Cronbach alpha (Nunnally, 1978). To be considered as reliable, these measures should hold an alpha coefficient in the range of 0.60, beyond 0.70 (Nunnally, 1978; Churchill, 1991; Litwin, 1995) or exceeding 0.50 (George \& Mallery, 2003). All measures in this study have high reliabilities above 0.60.

\begin{tabular}{|l|l|}
\hline Items & Cronbach Alpha \\
\hline 20 items on Pre-SIEP & 0.865 \\
\hline 20 items on SIEP Attachment & 0.845 \\
\hline 19 items on Post-SIEP & 0.938 \\
\hline
\end{tabular}

A total of 364 students participated in this study. There were 107 males and 257 females of which 291 are Malay, 61 are Chinese, 7 are Indians and 5 others. These respondents were in Year 2, 3 and 4 and were students of Faculty of Entrepreneurship and Business (173), Faculty of Agro and Natural Resources (143) and Faculty of Creative Technology and Heritage (48), as shown in Table 1.

Significantly, students' overall perceptions towards SIEP can be concluded as positive, referring to the moderately high mean score of above 3.00, on the likert scale of 1 being strongly disagree and 5 being strongly agree. The summary of mean score can be seen in Table 2. Breakdown of the mean score and comparison among the three Faculties could be seen in Appendix B. 
Table 1:- Characteristics of Respondents

\begin{tabular}{|l|l|c|c|}
\hline Gender & Male & Frequency & Percent \\
\hline & Female & 107 & 29.4 \\
\hline \multirow{5}{*}{ Ethnic } & Malay & 257 & 70.6 \\
\hline & Chinese & & \\
& Indian & 291 & 79.9 \\
\hline & Others & 61 & 16.8 \\
\hline Year of study & Year 2 & 7 & 1.9 \\
\hline & Year 3 & 5 & 1.4 \\
\hline & Year 4 & & \\
\hline & Missing data & 117 & 32.1 \\
\hline & Faculty of Entrepreneurship and Business & 158 & 43.4 \\
\hline & Faculty of Agro Industry and Natural Resources & 65 & 17.9 \\
\hline & Faculty of Creative Technology and Heritage & 143 & 6.6 \\
\hline
\end{tabular}

Table 2:- Mean Score of Students' Feedback for Pre-SIEP, during SIEP and Post- SIEP items

Descriptive Statistics

\begin{tabular}{|l|c|c|c|c|c|}
\hline & $\begin{array}{c}\text { Usable } \\
\text { Data }=\mathrm{N}\end{array}$ & Minimum & Maximum & Mean & $\begin{array}{c}\text { Std. } \\
\text { Deviation }\end{array}$ \\
\hline Mean PreSiep & 209 & 1.20 & 4.50 & 3.5227 & .48153 \\
Mean Siep & 212 & 1.80 & 4.65 & 3.4903 & .48169 \\
Mean PostSiep & 217 & 1.00 & 4.63 & 3.4795 & .60800 \\
\hline
\end{tabular}

Most importantly, researchers were pleased to discover that majority of the respondents reported positively on the attributes, skills and functional knowledge attained after SIEP. In terms of attributes, 70.3\% reported that they became more knowledgeable; $60.2 \%$ contended that they were more entrepreneurial and $51.1 \%$ concluded they became brave and dared to take risk through SIEP. This can be seen in Figure 1. Among the top skills acquired were communication (82.14\%); time management $(60.99 \%)$ and networking (50.5\%). Lastly, the functional knowledge gained include management (58.5\%) and entrepreneurship (58.5\%) being the highest, followed by operation (54.4\%) and marketing (45.9\%). Details of these findings could be seen in Table 3, 4 and 5 . 
Figure 1:- Attributes Gained Through SIEP

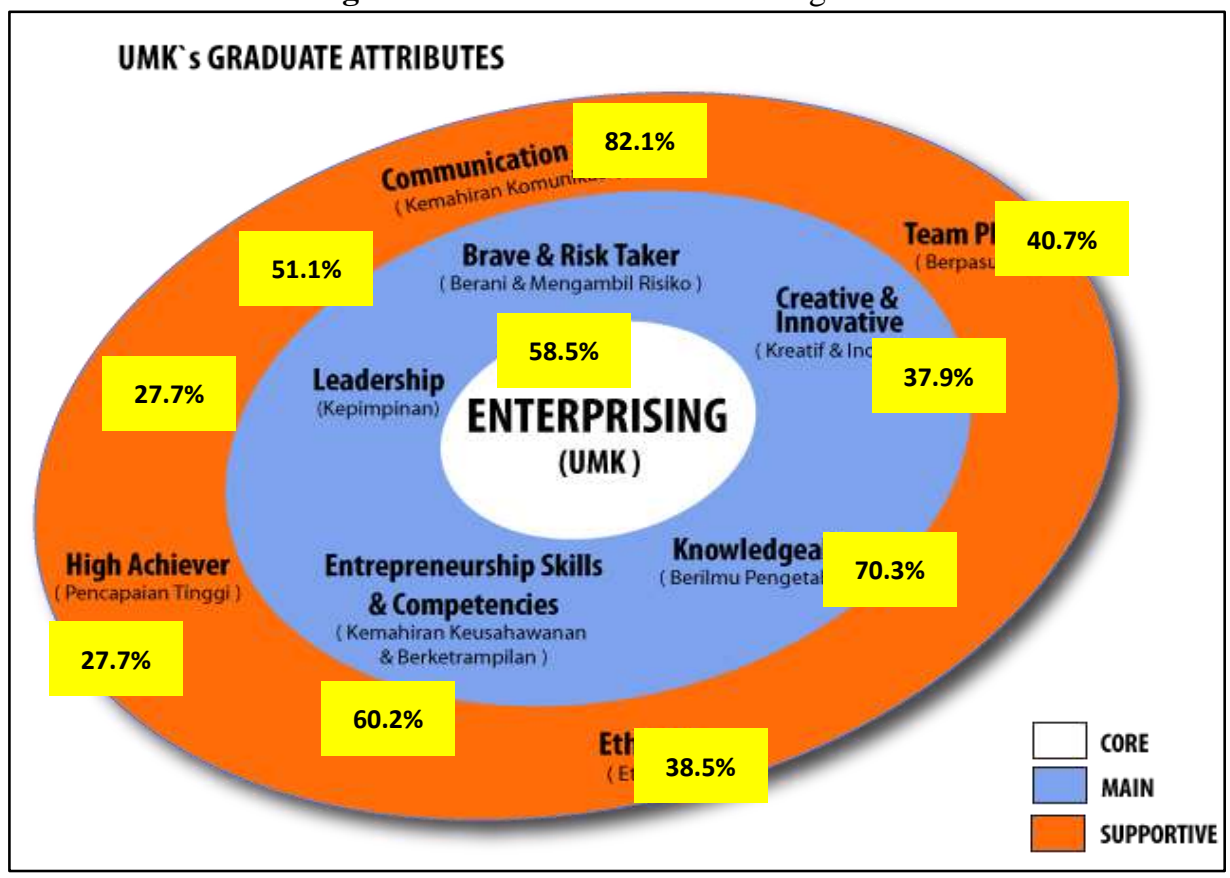

Table 3, 4 and 5:- Attributes, Skills and Functional Knowledge Acquired From SIEP

\begin{tabular}{|l|c|c|}
\hline \multicolumn{3}{|c|}{ Descriptive Statistics: $\mathbf{n}=\mathbf{3 6 4}$} \\
\hline \multicolumn{1}{|c|}{ Attribute } & Frequencies & Percentage \\
\hline Brave and risk taker & 186.00 & 51.1 \\
\hline Achievement-oriented & 101.00 & 27.7 \\
\hline Ethical & 140.00 & 38.5 \\
\hline Team Player & 148.00 & 40.7 \\
\hline Knowledgeable & 256.00 & 70.3 \\
\hline Entrepreneurial & 219.00 & 60.2 \\
\hline Proactive & 140.00 & 38.5 \\
\hline
\end{tabular}

\begin{tabular}{|l|c|c|}
\hline \multicolumn{3}{|c|}{ Descriptive Statistics: $\mathbf{n}=\mathbf{3 6 4}$} \\
\hline \multicolumn{1}{|c|}{ Skill } & Frequencies & Percentage \\
\hline Communication & 299.00 & 82.14 \\
\hline Leadership & 101.00 & 27.7 \\
\hline Creative and & 138.00 & \\
Innovative & & 37.9 \\
\hline Enterprising & 140.00 & 38.5 \\
\hline Networking & 184.00 & 50.5 \\
\hline Problem Solving & 170.00 & 46.7 \\
\hline Time Management & 222.00 & 60.99 \\
\hline
\end{tabular}

\begin{tabular}{|l|c|c|}
\hline \multicolumn{3}{|c|}{ Descriptive Statistics: $\mathbf{n}=\mathbf{3 6 4}$} \\
\hline Functional Knowledge & Frequencies & Percentage \\
\hline Management & 213.00 & 58.5 \\
\hline Marketing & 167.00 & 45.9 \\
\hline Finance/ Accounting & 107.00 & 29.4 \\
\hline Operation & 198.00 & 54.4 \\
\hline Information Technology & 101.00 & 27.7 \\
\hline Human Resource & 165.00 & 45.3 \\
\hline Entrepreneurship & 213.00 & 58.5 \\
\hline
\end{tabular}

\section{Conclusion:-}

Overall findings show that there is no negative feedback with regards to SIEP according to students from all the three faculties. Nonetheless, students did voice their concerns over several issues:

- It is not easy to find company for SIEP attachment;

- Monetary and non-monetary allowance are not provided by company (external factor which is not in the realm of UMK's responsibilities)

- Most supervisors do not invite to join the company after graduate (this is understandable since the attachment is quite short in period: only $10-14$ days)

- Students find 10-14 days period of attachment as adequate, thus it should not be extended or prolonged. 
Overall, findings show positive feedback given by students over the registration, administration and procedures before SIEP attachment; pleasant experience gained during SIEP attachment; satisfactory remark given for report writing and assessment done after SIEP; as well as the many attributes, skills and knowledge successfully acquired after SIEP program. Corrective measures and rooms for improvement include the following:

- Assist students to locate SMEs which are favorable to SIEP attachment. Each faculty could create a database of SMEs which has accepted SIEP attachment according to different states and post such data on the faculty website; students could then refer to and apply for in their coming semester. Such database will help link and strengthen the university-industry linkages.

- Although no negative feedback was given by students, the many aspects on Pre-SIEP and Post-SIEP could be further improved, as indicated by the mean scores which are beyond 3.00 but have yet to reach 4 and 5 .

Alternatively, a more comprehensive qualitative research could be done inviting more opinions from students and examining their concerns in a more systematic manner, leading to the many constructive ways to improve SIEP.

\section{References:-}

1. Churchill, G.A., 1991. Marketing Research: Methodological Foundation, fifth ed. The Dryden Press, New York.

2. Litwin, M.S., 1995. How to Measure Survey Reliability and Validity. Sage Publication, London.

3. Nunnally, J. C. (1978). Psychometric theory (2nd ed.). New York, NY: McGraw-Hill.

\section{APPENDIX A \\ Examining the Effectiveness and Impact of \\ Student In Enterprise Program (SIEP)}

Dear Student,

Thank you for participating in this research. The objectives of this study are to examine the implementation of SIEP in University Malaysia Kelantan, level of effectiveness and the impacts SIEP has brought about throughout the past four years. Your honest opinion is most appreciated and all responses will be kept private and confidential, used for academic purposes only. There is no right or wrong answers. Please kindly tick or circle the answer which best describes you.

\section{Section A: Demographic Details}

Please tick (/) the answer which best describes you.

1. Gender

Male [ ]

2. Ethnic

$\begin{array}{ll}\text { Malay [ ] } & \text { Indian [ ] } \\ \text { Chinese [ ] } & \text { Others [ ] Please state }\end{array}$

3. Year of Study

4. Faculty

Year 2 [ ] Year 3 [ ] Year 4 [ ]

Faculty of Entrepreneurship and Business [ ]

Faculty of Agro Industry and Natural Resources [ ]

Faculty of Creative Technology and Heritage [ ]

5. Field of study:

(for example: Bachelor of Entrepreneurship (Tourism)

6. State of Origin: (for example: Selangor)

Section B: Pre-SIEP

Kindly circle the number which best describes your opinion.

\begin{tabular}{|l|l|l|l|l|l|l|}
\hline Bil & Statement & $\begin{array}{l}\text { Strongly } \\
\text { Disagree }\end{array}$ & Disagree & Neutral & Agree & $\begin{array}{l}\text { Strongly } \\
\text { Agree }\end{array}$ \\
\hline 1 & I have a copy of SIEP guidebook. & 1 & 2 & 3 & 4 & 5 \\
\hline 2 & $\begin{array}{l}\text { I understand the instructions given in } \\
\text { SIEP guidebook. }\end{array}$ & 1 & 2 & 3 & 4 & 5 \\
\hline
\end{tabular}




\begin{tabular}{|c|c|c|c|c|c|c|}
\hline 3 & I understand the objectives of SIEP & 1 & 2 & 3 & 4 & 5 \\
\hline 4 & $\begin{array}{l}\text { I am aware of the numerous objectives } \\
\text { formulated for different phases of SIEP }\end{array}$ & 1 & 2 & 3 & 4 & 5 \\
\hline 5 & $\begin{array}{l}\text { I understand the numerous assignment/ } \\
\text { tasks stipulated by SIEP }\end{array}$ & 1 & 2 & 3 & 4 & 5 \\
\hline 6 & $\begin{array}{l}\text { I understand the variety of skills to be } \\
\text { achieved through participation in SIEP }\end{array}$ & 1 & 2 & 3 & 4 & 5 \\
\hline 7 & $\begin{array}{l}\text { I register for SIEP by submitting Borang } \\
\text { A (as given in the guidebook) }\end{array}$ & 1 & 2 & 3 & 4 & 5 \\
\hline 8 & $\begin{array}{l}\text { I have no problem in registering for SIEP } \\
\text { every semester }\end{array}$ & 1 & 2 & 3 & 4 & 5 \\
\hline 9 & $\begin{array}{l}\text { I understand the mechanism and } \\
\text { assessment (submission of logbook, report } \\
\text { and presentation) formulated for SIEP }\end{array}$ & 1 & 2 & 3 & 4 & 5 \\
\hline 10 & $\begin{array}{l}\text { I know the marks allocated for each of the } \\
\text { assessment (logbook, report, presentation) }\end{array}$ & 1 & 2 & 3 & 4 & 5 \\
\hline 11 & $\begin{array}{l}\text { I know the person-in-charge/ coordinator } \\
\text { overlooking SIEP in the Faculty }\end{array}$ & 1 & 2 & 3 & 4 & 5 \\
\hline 12 & $\begin{array}{l}\text { I look for placement or attachment (i.e. } \\
\text { company which I can work for) on my } \\
\text { own without anyone assistance }\end{array}$ & 1 & 2 & 3 & 4 & 5 \\
\hline 13 & $\begin{array}{l}\text { I decide on the company/ enterprise which } \\
\text { I want to work for }\end{array}$ & 1 & 2 & 3 & 4 & 5 \\
\hline 14 & $\begin{array}{l}\text { I choose a company/ enterprise which is } \\
\text { located near my place of residence }\end{array}$ & 1 & 2 & 3 & 4 & 5 \\
\hline 15 & $\begin{array}{l}\text { I do not mind travelling to a company/ } \\
\text { enterprise located quite far from my } \\
\text { residential area for SIEP }\end{array}$ & 1 & 2 & 3 & 4 & 5 \\
\hline 16 & $\begin{array}{l}\text { It is easy to find a company/ enterprise for } \\
\text { SIEP attachment }\end{array}$ & 1 & 2 & 3 & 4 & 5 \\
\hline 17 & $\begin{array}{l}\text { I rely on family/ relatives/ friend's } \\
\text { recommendations in looking for company/ } \\
\text { enterprise which can take me in for SIEP }\end{array}$ & 1 & 2 & 3 & 4 & 5 \\
\hline 18 & $\begin{array}{l}\text { I have problem looking for company/ } \\
\text { enterprise which can take me in for SIEP }\end{array}$ & 1 & 2 & 3 & 4 & 5 \\
\hline 19 & $\begin{array}{l}\text { Company/ enteprise involved in SIEP } \\
\text { allows me to work for a minimum of } 10 \\
\text { days }\end{array}$ & 1 & 2 & 3 & 4 & 5 \\
\hline 20 & $\begin{array}{l}\text { Company/ enterprise involved in SIEP } \\
\text { expects me to work for more than } 10 \text { days }\end{array}$ & 1 & 2 & 3 & 4 & 5 \\
\hline
\end{tabular}

Section C: SIEP Attachment

Kindly circle the number which best describes your opinion.

\begin{tabular}{|c|c|c|c|c|c|c|}
\hline Bil & Statement & $\begin{array}{l}\text { Strongly } \\
\text { Disagree }\end{array}$ & Disagree & Neutral & Agree & $\begin{array}{l}\text { Strongly } \\
\text { Agree }\end{array}$ \\
\hline 1 & $\begin{array}{l}\text { I always enjoy working in the company I } \\
\text { choose for SIEP. }\end{array}$ & 1 & 2 & 3 & 4 & 5 \\
\hline 2 & I am never absent for work during SIEP & 1 & 2 & 3 & 4 & 5 \\
\hline 3 & $\begin{array}{l}\text { Sometimes, I feel I choose the wrong } \\
\text { company/ enterprise for SIEP }\end{array}$ & 1 & 2 & 3 & 4 & 5 \\
\hline 4 & I learn a lot during SIEP & 1 & 2 & 3 & 4 & 5 \\
\hline 5 & $\begin{array}{l}\text { I acquire many skills and knowledge } \\
\text { during SIEP }\end{array}$ & 1 & 2 & 3 & 4 & 5 \\
\hline 6 & I am afraid to go to work & 1 & 2 & 3 & 4 & 5 \\
\hline 7 & The company/ enterprise provides & 1 & 2 & 3 & 4 & 5 \\
\hline
\end{tabular}




\begin{tabular}{|l|l|l|l|l|l|l|}
\hline 8 & monetary allowance & & & & \\
\hline 8 & $\begin{array}{l}\text { The company/ enterprise provides non- } \\
\text { monetary allowance (free meal) }\end{array}$ & 1 & 2 & 3 & 4 & 5 \\
\hline 9 & $\begin{array}{l}\text { The supervisor / owner guides me well } \\
\text { during SIEP }\end{array}$ & 1 & 2 & 3 & 4 & 5 \\
\hline 10 & $\begin{array}{l}\text { Colleagues are willing to coach me at } \\
\text { work }\end{array}$ & 1 & 2 & 3 & 4 & 5 \\
\hline 11 & $\begin{array}{l}\text { I do not learn anything in the company/ } \\
\text { enterprise }\end{array}$ & 1 & 2 & 3 & 4 & 5 \\
\hline 12 & $\begin{array}{l}\text { I write my diary or logbook on daily } \\
\text { basis }\end{array}$ & 1 & 2 & 3 & 4 & 5 \\
\hline 13 & $\begin{array}{l}\text { I write and fill in the logbook only after } \\
\text { SIEP attachment }\end{array}$ & 1 & 2 & 3 & 4 & 5 \\
\hline 14 & $\begin{array}{l}\text { The supervisor/ owner does not really } \\
\text { welcome me }\end{array}$ & 1 & 2 & 3 & 4 & 5 \\
\hline 15 & $\begin{array}{l}\text { The supervisor/ owner is satisfied with my } \\
\text { work performance }\end{array}$ & 1 & 2 & 3 & 4 & 5 \\
\hline 16 & $\begin{array}{l}\text { The supervisor/ owner requests me to } \\
\text { extend the period and work for more than } \\
10 \text { days }\end{array}$ & 1 & 2 & 3 & 4 & 5 \\
\hline 17 & $\begin{array}{l}\text { The supervisor/ owner invites me to join } \\
\text { their company/ enterprise after I graduate }\end{array}$ & 1 & 2 & 3 & 4 & 5 \\
\hline 18 & $\begin{array}{l}\text { The supervisor/ owner gives useful } \\
\text { feedback on how I can improve my work } \\
\text { performance }\end{array}$ & 1 & 2 & 3 & 4 & 5 \\
\hline 19 & $\begin{array}{l}\text { SIEP is very exciting } \\
\text { SIEP enriches my learning experience }\end{array}$ & 1 & 2 & 3 & 4 & 5 \\
\hline 20 & & & & & \\
\hline
\end{tabular}

Section D: Post-SIEP

Kindly circle the number which best describes your opinion.

\begin{tabular}{|l|l|l|l|l|l|l|}
\hline Bil & Statement & $\begin{array}{l}\text { Strongly } \\
\text { Disagree }\end{array}$ & Disagree & Neutral & Agree & $\begin{array}{l}\text { Strongly } \\
\text { Agree }\end{array}$ \\
\hline 1 & I have no problem producing SIEP report & 1 & 2 & 3 & 4 & 5 \\
\hline 2 & $\begin{array}{l}\text { I complete my logbook and submit on } \\
\text { time }\end{array}$ & 1 & 2 & 3 & 4 & 5 \\
\hline 3 & $\begin{array}{l}\text { I make sure the supervisor/ owner of the } \\
\text { company fill up the evaluation form }\end{array}$ & 1 & 2 & 3 & 4 & 5 \\
\hline 4 & $\begin{array}{l}\text { SIEP coordinator assign relevant } \\
\text { examiner to assess my SIEP report and } \\
\text { presentation }\end{array}$ & 1 & 2 & 3 & 4 & 5 \\
\hline 5 & $\begin{array}{l}\text { I am always satisfied with my SIEP } \\
\text { performance }\end{array}$ & 1 & 2 & 3 & 4 & 5 \\
\hline 6 & $\begin{array}{l}\text { I am satisfied with the grades given for } \\
\text { SIEP }\end{array}$ & 1 & 2 & 3 & 4 & 5 \\
\hline 7 & $\begin{array}{l}\text { I am satisfied with the feedback given by } \\
\text { my examiner }\end{array}$ & 1 & 2 & 3 & 4 & 5 \\
\hline 8 & $\begin{array}{l}\text { I try to improve the grade attained for } \\
\text { SIEP every semester } \\
\text { The period for SIEP (10 days - 14 days) } \\
\text { is too short }\end{array}$ & 1 & 2 & 3 & 4 & 5 \\
\hline 9 & $\begin{array}{l}\text { Students should be proactive and work for } \\
\text { more than } 10 \text { days for SIEP }\end{array}$ & 1 & 2 & 3 & 4 & 5 \\
\hline 10 & $\begin{array}{l}\text { I gain many skills and knowledge through } \\
\text { SIEP program }\end{array}$ & 1 & 2 & 3 & 4 & 5 \\
\hline 11 & SIEP has given me very valuable work & 1 & 2 & 3 & 4 & 5 \\
\hline 12 & & & 4 & 5 \\
\hline
\end{tabular}




\begin{tabular}{|c|c|c|c|c|c|c|}
\hline & experience & & & & & \\
\hline 13 & $\begin{array}{l}\text { I appreciate and treasure SIEP because I } \\
\text { acquire hands-on experience }\end{array}$ & 1 & 2 & 3 & 4 & 5 \\
\hline 14 & I become more confident after SIEP & 1 & 2 & 3 & 4 & 5 \\
\hline 15 & $\begin{array}{l}\text { SIEP prepares me well for joining the } \\
\text { workforce later }\end{array}$ & 1 & 2 & 3 & 4 & 5 \\
\hline 17 & $\begin{array}{l}\text { SIEP prepares me well for my industrial } \\
\text { training }\end{array}$ & 1 & 2 & 3 & 4 & 5 \\
\hline 18 & Overall, SIEP is a good program & 1 & 2 & 3 & 4 & 5 \\
\hline 19 & $\begin{array}{l}\text { Universiti Malaysia Kelantan should } \\
\text { continue to implement SIEP }\end{array}$ & 1 & 2 & 3 & 4 & 5 \\
\hline 20 & $\begin{array}{l}\text { All universities in Malaysia should } \\
\text { consider implementing SIEP besides } \\
\text { industrial training at the end of final year }\end{array}$ & 1 & 2 & 3 & 4 & 5 \\
\hline
\end{tabular}

Section E: Attributes, Skills and Functional Knowledge Gained through SIEP

Which of the following attributes, skills and functional knowledge do you gain after joining SIEP? You may tick more than one.

\begin{tabular}{|l|l|l|l|l|}
\hline Attributes & Skills & & Functional Knowledge & \\
\hline Brave and risk taker & Communication & & Management & \\
\hline Achievement-oriented & Leadership & & Marketing & \\
\hline Ethical & Creative and Innovative & & Finance/ Accounting & \\
\hline Team Player & Enterprising & & Operation & \\
\hline Knowledgeable & Networking & & Information Technology & \\
\hline Entrepreneurial & Problem Solving & & Human Resource & \\
\hline Proactive & Time Management & & Entrepreneurship & \\
\hline
\end{tabular}

For attributes, skills and functional knowledge gained other than those stated above, please state:

\section{Section F: Suggestions/ Recommendations}

You are invited to place any comments you have for SIEP. You may also suggest how SIEP can be further improved.

THANK YOU FOR YOUR PARTICIPATION 


\section{APPENDIX B}

Comparison of Mean Score among Faculties (Pre-SIEP items)

\begin{tabular}{|c|c|c|c|c|}
\hline PresIEP (Item 1 to 10 ) & FEB & FASA & FTKW & $\begin{array}{l}\text { Overall } \\
\text { Mean }\end{array}$ \\
\hline I have a copy of SIEP guidebook. & 4.2023 & 4.1888 & 3.5000 & 4.0495 \\
\hline $\begin{array}{l}\text { I understand the instructions given in SIEP } \\
\text { guidebook. }\end{array}$ & 3.7630 & 3.6241 & 3.2391 & 3.6500 \\
\hline I understand the objectives of SIEP. & 3.6628 & 3.4859 & 3.4468 & 3.6182 \\
\hline $\begin{array}{l}\text { I am aware of the numerous objectives formulated } \\
\text { for different phases of SIEP }\end{array}$ & 3.3743 & 3.3286 & 3.1395 & 3.3256 \\
\hline $\begin{array}{l}\text { I understand the numerous assignment/ tasks } \\
\text { stipulated by SIEP }\end{array}$ & 3.4327 & 3.2606 & 3.2083 & 3.3773 \\
\hline $\begin{array}{l}\text { I understand the variety of skills to be achieved } \\
\text { through participation in SIEP }\end{array}$ & 3.6416 & 3.4545 & 3.1875 & 3.5405 \\
\hline $\begin{array}{l}\text { I register for SIEP by submitting Borang A (as given } \\
\text { in the guidebook) }\end{array}$ & 4.2543 & 3.5070 & 3.4468 & 4.0769 \\
\hline $\begin{array}{l}\text { I have no problem in registering for SIEP every } \\
\text { semester }\end{array}$ & 3.7558 & 3.3357 & 3.3750 & 3.6697 \\
\hline $\begin{array}{l}\text { I understand the mechanism and assessment } \\
\text { (submission of logbook, report and presentation) } \\
\text { formulated for SIEP }\end{array}$ & 3.7110 & 3.3846 & 3.2708 & 3.6171 \\
\hline $\begin{array}{l}\text { I know the marks allocated for each of the } \\
\text { assessment (logbook, report, presentation) }\end{array}$ & 3.6358 & 3.3427 & 3.2292 & 3.5450 \\
\hline PreSIEP (Item 10 to 20 ) & FEB & FASA & FTKW & $\begin{array}{l}\text { Overall } \\
\text { Mean }\end{array}$ \\
\hline $\begin{array}{l}\text { I know the person-in-charge/ coordinator overlooking } \\
\text { SIEP in the Faculty }\end{array}$ & 3.4220 & 3.5944 & 3.3958 & 3.4099 \\
\hline $\begin{array}{l}\text { I look for placement or attachment (i.e. company which I } \\
\text { can work for) on my own without anyone assistance }\end{array}$ & 3.6570 & 3.5563 & 3.4167 & 3.6018 \\
\hline $\begin{array}{l}\text { I decide on the company/ enterprise which I want to work } \\
\text { for }\end{array}$ & 3.9075 & 3.7622 & 3.4583 & 3.8063 \\
\hline $\begin{array}{l}\text { I choose a company/ enterprise which is located near my } \\
\text { place of residence }\end{array}$ & 4.0405 & 3.7746 & 3.5435 & 3.9318 \\
\hline $\begin{array}{l}\text { I do not mind travelling to a company/ enterprise located } \\
\text { quite far from my residential area for SIEP }\end{array}$ & 3.1965 & 2.9790 & 3.0417 & 3.1577 \\
\hline $\begin{array}{l}\text { It is easy to find a company/ enterprise for SIEP } \\
\text { attachment }\end{array}$ & 2.7457 & 2.5035 & 2.9792 & 2.7973 \\
\hline $\begin{array}{l}\text { I rely on family/ relatives/ friend's recommendations in } \\
\text { looking for company/ enterprise which can take me in for } \\
\text { SIEP }\end{array}$ & 3.1561 & 3.1049 & 3.2708 & 3.1847 \\
\hline $\begin{array}{l}\text { I have problem looking for companyl enterprise which } \\
\text { can take me in for SIEP (recoded) }\end{array}$ & 2.9249 & 2.5944 & 2.9375 & 2.9234 \\
\hline $\begin{array}{l}\text { Company/ enterprise involved in SIEP allows me to work } \\
\text { for a minimum of } 10 \text { days }\end{array}$ & 3.3988 & 3.2606 & 3.0417 & 3.3198 \\
\hline $\begin{array}{l}\text { Company/ enterprise involved in SIEP expects me to } \\
\text { work for more than } 10 \text { days }\end{array}$ & 3.6647 & 2.9577 & 3.2708 & 66 \\
\hline
\end{tabular}


Comparison of Mean Score among Faculties (During SIEP items)

\begin{tabular}{|l|r|r|r|r|}
\hline \multicolumn{1}{|c|}{ During SIEP (Item 1 to 10) } & \multicolumn{1}{|c|}{ FEB } & \multicolumn{1}{|c|}{ FASA } & \multicolumn{1}{|c|}{ FTKW } & \multicolumn{1}{c|}{$\begin{array}{l}\text { Merall } \\
\text { Mean }\end{array}$} \\
\hline $\begin{array}{l}\text { I always enjoy working in the company I choose for } \\
\text { SIEP. }\end{array}$ & 3.6453 & 3.2324 & 3.5000 & 3.4641 \\
\hline I am never absent for work during SIEP & 4.1279 & 3.5461 & 3.6042 & 3.8310 \\
\hline $\begin{array}{l}\text { Sometimes, I feel I choose the wrong company/ } \\
\text { enterprise for SIEP }\end{array}$ & 3.2733 & 3.1135 & 2.9574 & 3.1694 \\
\hline I learn a lot during SIEP & 3.8663 & 3.6241 & 3.5833 & 3.7341 \\
\hline I acquire many skills and knowledge during SIEP & 3.8012 & 3.5674 & 3.6957 & 3.6955 \\
\hline I am afraid to go to work & 3.7500 & 3.4894 & 3.0417 & 3.5540 \\
\hline The company/ enterprise provides monetary allowance & 2.6395 & 1.9930 & 3.2708 & 2.4696 \\
\hline $\begin{array}{l}\text { The company/ enterprise provides non-monetary } \\
\text { allowance (free meal) }\end{array}$ & 2.7283 & 2.2676 & 3.3542 & 2.6309 \\
\hline The supervisor / owner guides me well during SIEP & 3.5814 & 3.1831 & 3.1875 & 3.3729 \\
\hline Colleagues are willing to coach me at work & 3.4971 & 3.2643 & 3.1667 & 3.3629 \\
\hline
\end{tabular}

\begin{tabular}{|c|c|c|c|c|}
\hline During SIEP (Item 11 to 20 ) & FEB & FASA & FTKW & $\begin{array}{l}\text { Overall } \\
\text { Mean }\end{array}$ \\
\hline I do not learn anything in the company/ enterprise & 3.9595 & 3.6268 & 3.2766 & 3.7403 \\
\hline I write my diary or logbook on daily basis & 3.8555 & 3.6479 & 3.3125 & 3.7025 \\
\hline $\begin{array}{l}\text { I write and fill in the logbook only after SIEP } \\
\text { attachment }\end{array}$ & 3.0349 & 3.2183 & 3.1915 & 3.1274 \\
\hline The supervisor/ owner does not really welcome me & 3.8671 & 3.2553 & 3.2083 & 3.5414 \\
\hline $\begin{array}{l}\text { The supervisor/ owner is satisfied with my work } \\
\text { performance }\end{array}$ & 3.8208 & 3.4429 & 3.3125 & 3.6066 \\
\hline $\begin{array}{l}\text { The supervisor/ owner requests me to extend the } \\
\text { period and work for more than } 10 \text { days }\end{array}$ & 3.6879 & 2.8873 & 3.4375 & 3.3416 \\
\hline $\begin{array}{l}\text { The supervisor/ owner invites me to join their } \\
\text { company/ enterprise after I graduate }\end{array}$ & 3.0347 & 2.7183 & 3.2708 & 2.9421 \\
\hline $\begin{array}{l}\text { The supervisor/ owner gives useful feedback on how I } \\
\text { can improve my work performance }\end{array}$ & 3.5434 & 3.2042 & 3.4583 & 3.3994 \\
\hline SIEP is very exciting & 3.2890 & 2.8169 & 3.1875 & 3.0909 \\
\hline SIEP enriches my learning experience & 3.5988 & 3.3214 & 3.4565 & 3.4721 \\
\hline
\end{tabular}

Comparison of Mean Score among Faculties (Post SIEP items) 


\begin{tabular}{|c|c|c|c|c|}
\hline PostSIEP (Item 1 to 10 ) & FEB & FASA & FTKW & $\begin{array}{l}\text { Overall } \\
\text { Mean }\end{array}$ \\
\hline I have no problem producing SIEP report & 3.1965 & 2.8803 & 2.9375 & 3.0386 \\
\hline I complete my logbook and submit on time & 3.9133 & 3.3662 & 3.2553 & 3.6133 \\
\hline $\begin{array}{l}\text { I make sure the supervisor/ owner of the company fill up } \\
\text { the evaluation form }\end{array}$ & 3.9769 & 3.7254 & 3.3542 & 3.7961 \\
\hline $\begin{array}{l}\text { SIEP coordinator assigns relevant examiner to assess } \\
\text { my SIEP report and presentation }\end{array}$ & 3.4302 & 3.4000 & 3.1250 & 3.3778 \\
\hline I am always satisfied with my SIEP performance & 3.4220 & 3.1338 & 3.3125 & 3.2948 \\
\hline I am satisfied with the grades given for SIEP & 3.3410 & 3.0141 & 3.2083 & 3.1956 \\
\hline I am satisfied with the feedback given by my examiner & 3.4046 & 3.2979 & 3.2917 & 3.3481 \\
\hline $\begin{array}{l}\text { I try to improve the grade attained for SIEP every } \\
\text { semester }\end{array}$ & 4.0520 & 3.8014 & 3.3333 & 3.8591 \\
\hline The period for SIEP ( 10 days -14 days) is too short & 2.9249 & 2.3050 & 3.1667 & 2.7155 \\
\hline $\begin{array}{l}\text { Students should be proactive and work for more than } 10 \\
\text { days for SIEP }\end{array}$ & 3,1098 & 2.5000 & 3.2292 & 2.8871 \\
\hline PostSIEP (Item 11 to 19 ) & FEB & FASA & FTKW & $\begin{array}{l}\text { Overall } \\
\text { Mean }\end{array}$ \\
\hline $\begin{array}{l}\text { gain many skills and knowledge through SIEP } \\
\text { program }\end{array}$ & 3.7341 & 3.3873 & 3.3542 & 3.5482 \\
\hline SIEP has given me very valuable work experience & 3.7267 & 3.4155 & 3.3542 & 3.5552 \\
\hline $\begin{array}{l}\text { I appreciate and treasure SIEP because I acquire } \\
\text { hands-on experience }\end{array}$ & 3.6474 & 3.3380 & 3.2917 & 3.4793 \\
\hline I become more confident after SIEP & 3.5145 & 3.3404 & 3.3404 & 3.4238 \\
\hline SIEP prepares me well for joining the workforce later & 3.6185 & 3.3310 & 3.3617 & 3.4724 \\
\hline SIEP prepares me well for my industrial training & 3.5896 & 3.2887 & 3.2083 & 3.4215 \\
\hline Overall, SIEP is a good program & 3.5607 & 3.2254 & 3.3750 & 3.4050 \\
\hline $\begin{array}{l}\text { Universiti Malaysia Kelantan should continue to } \\
\text { implement SIEP }\end{array}$ & 3.4535 & 3.0634 & 3.3958 & 3.2928 \\
\hline $\begin{array}{l}\text { All universities in Malaysia should consider } \\
\text { implementing SIEP besides industrial training at the } \\
\text { end of final year }\end{array}$ & 3.5434 & 3.1489 & 3.4167 & 3.3729 \\
\hline
\end{tabular}

